\title{
The formation in physical education in a multiprofessional dialogue aiming the promotion of health
}

\section{A formação em educação física no diálogo multiprofissional para a promoção da saúde}

Allyson Carvalho de Araújo

Maria Aparecida Dias

José Pereira de $\mathrm{Melo}^{1}$

\begin{abstract}
The Health and Citizenship Integrated Education Activity, was created in the semester of 2000.2, at the initiative of the Federal University of Rio Grande do Norte (UFRN), with the purpose of making the health courses more flexible and has assumed pivotal role in the changing process of the formation of health professionals. The Physical Education course UFRN has appropriated of this formation space to gradually lodge curricular components to potentiate the health promotion. The purpose of the paper is to present the integration of Physical Education course UFRN along a curricular component common to other health courses. This is a pedagogical experience report methodologically characterized as exploratory study of descriptive character of qualitative approach. It appears that the entering of physical education provided extensions of perception on health promotion through physical activity in students and teachers from several courses in the field of health.
\end{abstract}

\section{Keywords}

Motor Activity; Health Promotion; Human Resources Formation; Curriculum.

\section{Resumo}

A Atividade Integrada de Educação, Saúde e Cidadania foi criada no periodo letivo de 2000.2, por iniciativa da Universidade Federal do Rio Grande do Norte (UFRN), com o propósito de flexibilização dos Cursos da Área da Saúde e tem assumido papel estruturante de mudanças na formação dos profissionais da saúde. O curso de Educação Física da UFRN apropriou-se desse espaço de formação para implantar gradativamente componentes curriculares potencializadores da promoção da saúde. $O$ objetivo do texto é apresentar a inserção do curso de Educação Física da UFRN junto a um componente curricular comum aos demais cursos de saúde. Trata-se de um relato de experiência pedagógica caracterizado metodologicamente como estudo exploratório de caráter descritivo de abordagem qualitativa. Constata-se que o ingresso da Educação física propiciou ampliaçôes da percepção de promoção da saúde por meio da atividade física em alunos e professores de diversos cursos da área da saúde.

\section{Palavras-chave}

Atividade física; Promoção da saúde; Formação de Recursos Humanos; Currículo.
Rev Bras Ativ Fis Saúde p. 339-343 DOI:

http://dx.doi.org/10.12820/rbafs.v.18n3p339

1 Grupo de Estudo Corpo e Cultura de Movimento, Universidade Federal do Rio Grande do Norte. Departamento de Educação Física. Natal, RN, Brasil. 


\section{INTRODUCTION}

Seeking changes in the professional training of its undergraduate students enrolled in various health courses, the Universidade Federal do Rio Grande do Norte (UFRN - Federal University of Rio Grande do Norte) established the Atividade Integrada de Educação, Saúde e Cidadania (SACI - Integrated Activity of Education, Health and Citizenship) in the $2^{\text {nd }}$ academic semester of 2000. This curricular component is the result of reflections about the new health care paradigm, which has been discussed since the 1970s with the Brazilian Health Reform Movement. Among the several discussions raised, the need to change the professional training of health professionals was emphasized, due to the new concept of collective health. The professional training process of human resources in the area of health is experiencing a time when a flow of new ideas about the hospital-centered Flexnerian model ${ }^{1}$ is arising. This model is characterized by strong technological incorporation, excessive drug use, fragmentation of knowledge and theory-practice dichotomy, not being associated with the social-health context.

Therefore, the SACI includes proposals for changes in professional training and is characterized as a teaching-learning process aimed at promoting interdisciplinary practices and teaching-service-community integration by allowing the inclusion of first-year undergraduate students in practical learning situations and enabling a view of reality based on the National Health Promotion Policy ${ }^{2}$ and on the required inter-professional education directed towards collaborative health practices $^{3}$. When dealing with community-related issues through health and citizenship actions, integrated activities stimulate the participation of several social participants, such as professors, students and health professionals ${ }^{4}$.

The methodology used in this curricular component has prioritized educational aspects of the Critical School with a problem-posing approach, which establishes the preceptor's role as the facilitator of the teaching-learning process and understands students as active subjects. As a multi-professional curricular component in the UFRN's health training and approaching the Freirean perspective of education ${ }^{5}$, the SACI promotes the constant movement between action-reflection-action by providing moments of shared experience of the contents by studying a certain region covered by a Family Health Unit. To achieve this, an integrated activity is developed according to the following three main steps during each academic semester:

- Study of reality - It includes exploratory moments in the area covered by Family Health Units;

- Organization of data on reality - It includes the diagnosis of the situation in such area by identifying the local problems and potentials;

- Intervention in the reality - In includes the development and execution of an intervention plan that deals with a certain key issue of the community, which can be observed by the group and contribute to health promotion.

The evaluation process occurs on a daily basis during the entire semester to check students' learning and the concrete result of this experience. The following are used to assess the process: a Portfolio, such as daily field records; a Performance Assessment File; and an Intervention Project and Report.

This teaching model based on health training problems has its inspiration in the University of Hawaii ${ }^{6}$ in the 1980s, graphically represented by the Arc method image suggested by Charles Maguerez ${ }^{7}$, as shown in Figure 1. 


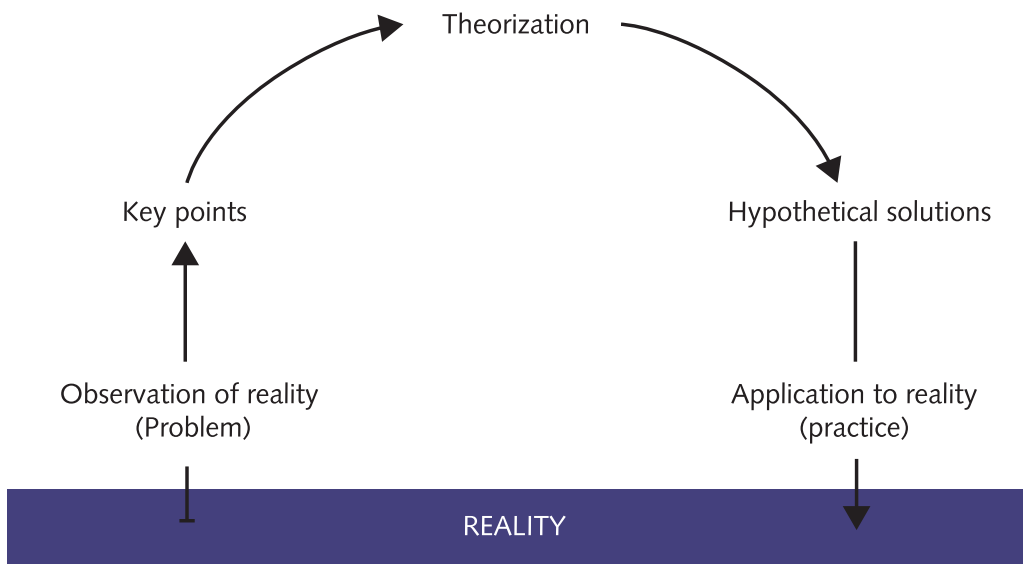

Figure 1 - Teaching-learning process model based on Maguerez' Arc.

The curricular component design is comprised by students of several courses, under the guidance of a tutor-professor and the collaboration of preceptors of several health areas which leave the university campus to understand the social reality of the local population and to propose health promotion strategies. The SACI is understood as a curricular experiment that reflects the advances in the debate about the directives on professional training in the health area, due to its multi-professional nature.

According to the institutional assessment, the dynamics involved in this curricular component has developed the autonomy of students and their recognition as social transformation agents, in addition to promoting the broadening of awareness of what the health-disease process could become when associated with the area covered by a Family Health Unit. According to the reports of students and the general population, it could be observed that the university intervention projects collaborating to local themes were accepted.

The present study aimed to show the inclusion of the UFRN's undergraduate course in Physical Education in the curricular component shared by the remaining health courses. This study was comprised of a report on the educational experience of higher education in the area of health, making use of the systematic and participant observation of a professor from the Department of Physical Education. During three academic semesters ( $2^{\text {nd }}$ academic semester of 2011 and $1^{\text {st }}$ and $2^{\text {nd }}$ academic semesters of 2012), this professor was responsible for the tutoring of a group of students from different areas of health, in one of the Primary Health Units situated in the northern area of the city of Natal, RN, Northeastern Brazil.

\section{The inclusion of the undergraduate course in Physical Education in the debate about health promotion in a multi-professional and interdisciplinary way}

Based on the professional training directions that led to the distinctions between the Teaching degree and the Bachelor's degree in Physical Education in the first half of the previous decade ${ }^{8,9}$, several higher education institutions sought to give an identity to the Bachelor's degree through several approaches. During its first eight years of existence, the UFRN's Bachelor's degree program in Physical Education included debates about physical education, health and quality of life as the foundation of its educational project and gradually sought to include components that promoted health in its curriculum. However, the efforts lacked a clearer perception of the role of the Physical Education professional in health services. 
With the emergence of the National Health Promotion Policy ${ }^{10}$ which categorically included physical activities as elements of health promotion, and the subsequent opportunities provided to Physical Education professionals in the sphere of professional practice in primary health care, with the creation of Family Health Strategy Support Centers ${ }^{11}$, the perspectives of professional training for health promotion have become ever clearer and more encouraged by experts in the area of Physical Education for Health ${ }^{12}$.

Aiming to learn from the successful experiences found in the institution itself, the undergraduate course in Physical Education of the UFRN has included the SACI curricular component since the $2^{\text {nd }}$ academic semester of 2011. Within the scope of such curricular component, 15 teaching positions for this course have been initially made available and a new tutorial group has been created under the responsibility of a professor from the Department of Physical Education (DEF/UFRN).

It should be emphasized that, as a tutorial group, the SACI is comprised of one IFES professor, preceptors from different health areas and students from distinct courses in the area of health of higher education institutions (Medicine, Nursing, Dentistry, Speech Therapy, Nutrition, Physical Education etc.) present in a Primary Health Unit of the city of Natal.

From the perspective of the Department of Physical Education of the UFRN, which joined the SACI tutoring program, the inclusion of Physical Education professionals and students in tutorial groups has increased the visibility of physical activities as an element that triggers both the health promotion process through physical activity and the exercise of citizenship through popular mobilization.

In the three semesters following the inclusion of the SACI in the undergraduate course of Physical Education, students from several areas of health continued to establish contact with the community through exploratory trips, which enables the understanding of the social reality and the identification of problems affecting certain areas. Among the limitations identified by students and recorded in Portfolios in several tutorial groups, the following can be pointed out: lack of health professionals caring for the population; lack of medications; absence of social equipment; child labor; poor basic sanitation; accumulation of garbage; poor access to health units; and drug use and trafficking.

Mapping out the reality was important as it enabled students to understand the social context and the health-disease process experienced by the local population, which are not only associated with biological aspects, but rather with social dynamic factors ${ }^{13,14}$. The access to information for the identification of a certain region always involved the selection of skills relevant to each health area for community intervention. However, the repeated performance of thematic interventions connected with the promotion of groups or spaces for physical activities has been noticeable. This can be observed in the section of Table 1 that shows three tutorial groups supervised by a professor from the Department of Physical Education of the UFRN, responsible for tutorial groups spread across the city of Natal (RN).

\section{FINAL CONSIDERATIONS}

The experience accumulated in these three first academic semesters and the indicators previously mentioned in the form of interventions performed by students in the area of health have strengthened professional training in Physical Education, at the same time that the notion of strategic space for physical activities in this area is developed. Additionally, the experience shows that the UFRN has advanced to fill the gap caused by the unavailability of disciplines that include Public/Collec- 


\begin{tabular}{|l|l|l|l|l|}
\hline \multicolumn{1}{|c|}{$\begin{array}{c}\text { Academic } \\
\text { semester }\end{array}$} & Tutorial group/region & $\begin{array}{c}\text { Number of Physical } \\
\text { Education students and/ } \\
\text { or preceptors }\end{array}$ & $\begin{array}{c}\text { Theme of the inter- } \\
\text { vention }\end{array}$ & \multicolumn{1}{c|}{$\begin{array}{c}\text { Relationship with physical activity } \\
\text { promotion }\end{array}$} \\
\hline $\begin{array}{l}2^{\text {nd }} \text { semester } \\
\text { of } 2011\end{array}$ & UBS Panatis & 01 & $\begin{array}{l}\text { Popular mobilization } \\
\text { and citizenship }\end{array}$ & $\begin{array}{l}\text { Claim-oriented, in the sense that spaces for } \\
\text { physical activities are demanded from the } \\
\text { responsible authorities, among other claims. }\end{array}$ \\
\hline $\begin{array}{l}1^{\text {st }} \text { semester } \\
\text { of } 2012\end{array}$ & UBS Panatis & 02 & $\begin{array}{l}\text { Humanization, welcom- } \\
\text { ing and leisure }\end{array}$ & $\begin{array}{l}\text { Creation of a space for leisure and physical } \\
\text { activities in the UBS premises. }\end{array}$ \\
\hline $\begin{array}{l}2^{\text {nd }} \text { semester } \\
\text { of } 2012\end{array}$ & $\begin{array}{l}\text { UBS Planície das } \\
\text { Mangueiras }\end{array}$ & 01 & UBS walking group & $\begin{array}{l}\text { Promotion and monitoring of a physical } \\
\text { activity group comprised of UBS users. }\end{array}$ \\
\hline
\end{tabular}

Table 1 - Summary of interventions of tutorial groups and their relationships with physical activity promotion.

tive Health contents. Valuing such practices in early professional training means to consider the health training practices regulated by inter-professional education. Our aim is to provide health services that prioritize the promotion of physical activities to the population.

\section{REFERENCES}

1. Almeida Filho N. Reconhecer Flexner: inquérito sobre produção de mitos na educação médica no Brasil contemporâneo. Cad. Saúde Pública. 2010; 26(12): 2234-2249.

2. ORGANIZAÇÃO MUNDIAL DE SAÚDE. Marco para Ação em Educação Interprofissional e Prática Colaborativa [online]. 2010. Disponível em: http://www.fm.usp.br/gdc/docs/ preventiva_170_marco_para_acao.pdf

3. Brasil. Política nacional de promoção da saúde. Brasília: Ministério da Saúde, Secretaria de Vigilância em Saúde, Secretaria de Atenção à Saúde; 2006.

4. Medeiros Jr A, Liberalino FN, Costa NDL (eds). Caminhos da tutoria e aprendizagem em saúde e cidadania. Natal: EDUFRN; 2011.

5. Freire P. Pedagogia da autonomia: saberes necessários à prática educativa. São Paulo: Paz e Terra, 1996.

6. Mitre SM, Siqueira-Batista R, Girarde-de-Mendonça JM, Morais-Pinto NM, Meirelles CAB, Pinto-Porto C, et al. Metodologias ativas de ensino-aprendizagem na formação profissional em saúde: debates atuais. Ciência \& Saúde Coletiva. 2008; 13(Supl. 2): 2133-2144.

7. Bordenave PA. A estratégia de ensino aprendizagem. Petrópolis: Vozes, 2005.

8. Brasil. Ministério da Educação. Conselho Nacional de Educação/Conselho Pleno. Resolução n 1, de 18 de fevereiro de 2002. Institui Diretrizes Curriculares Nacionais para a formação de professores da Educação Básica, em nível superior, curso de licenciatura, de graduação plena; 2002.

9. Brasil. Ministério da Educação. Conselho Nacional de Educação/Câmara de Educação Superior. Resolução n ${ }^{\circ}$ 7, de 31 de março de 2004. Institui as Diretrizes Curriculares Nacionais para os cursos de graduação em Educação Física, em nível superior de graduação plena; 2004.

10. Brasil, Ministério da Saúde, Secretaria de Vigilância em Saúde. Política Nacional de Promoção da Saúde. Brasília: Ministério da Saúde; 2006.

11. Brasil, Ministério da Saúde, Secretaria de Vigilância em Saúde. Portaria no 154 de 24 de janeiro de 2008. Cria os Núcleos de Apoio à Saúde da Familia - NASF. Brasília: Ministério da Saúde; 2008.

12. Fonseca AS, Menezes AS, Loch MR, Feitosa WMN, Nahas MV, Nascimento JV. Pela criação da Associação Brasileira de Ensino da Educação Física para a Saúde: Abenefs. Rev Bras Ativ Fis e Saúde. 2011; 16(4): 283-288.

13. Laurell AC. La salud-enfermedad como proceso social. Revista Latinoamericana de Salud. 1982; 2: 7-25.

14. Mendes MIB. S. Mens Sana in Copore Sano: saberes e práticas sobre corpo e saúde. Porto Alegre: Sulinas, 2007.

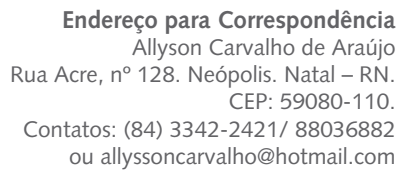

Received 06/19/2013

Revised 08/21/2013

Approved 08/21/2013 